\title{
Photojournalism as a Creator of Values: otherness in Sámi representations
}

\author{
HELI LEHTELÄ, University of Lapland
}

\section{ABSTRACT}

The research draws on the insights provided by photojournalism to examine the values and value formation of journalism in relation to power and ethnic minorities. News photos are representations which affect emotions; they engender meanings about reality and settings more subtly than texts. Photojournalism makes value judgments on issues, groups and persons through the size of the photos, settings, poses, the roles depicted, and simply by choosing who is photographed.

The material to be analysed consists of news photos dealing with the Sámi published in the Arctic press. My particular focus is the news items dealing with the Sámi and how the ethnic minority is depicted in those representations. The methods to be used are content analysis and formal photo analysis. I use the concept of otherness for determining journalists' valuations. A simple definition of otherness could be 'being an outsider'.

\section{KEYWORDS}

photojournalism, representation, the Sámi, otherness, content analysis, formal photo analysis.

\section{Introduction}

Photojournalism is taking on a bigger and bigger role in society. Several studies show that people direct their attention mainly to headlines, photos and captions when reading the newspaper (Miettinen 1980, p.247). News photos are representations which affect emotions. They engender meanings about reality and settings more subtly than texts demanding less activity from reader than journalistic texts (Loiri and Juholin, 1998, p.53).

My study is photojournalistic research dealing with visual communication and news photos. Each cultural world operates according to its own principles and norms. They form a basis also for journalistic norms and unwritten practices created for guaranteeing the quality of the news. The news reported according to these norms and practices tells about the issues and people that are significant in society. In addition to common journalistic rules, every newspaper has its own policies for representing issues. Who and what is to be photographed and how are significant questions for ascertaining the values of the media in varying cultures. Each press picture itself tells about appraisals, selections and preferences - what we value and the choices we make. Photojournalism valuates issues, groups, and persons through, for example, settings, poses and the roles depicted. Also, the placement of visual elements reveals valuations and creates meanings. The most important news items take the most space 
in the newspaper and are situated in the best places in the lay-out. The same rules apply when selecting photos. The most important persons and issues are given a prominent place, leaving less important issues in the background. The size of a news photo and its location on the page are not irrelevant.

There are basically two kinds of pictorial material in newspapers: advertisement pictures and journalistic pictures. I focus here on the journalistic representations of the Sámi in press photos to determine the valuations in the media. The Sámi, who live in Norway, Sweden, Finland and Russia, are the only indigenous people in Europe. The Sámi area of Finland is defined in legislation as the municipalities of Utsjoki, Inari, Enontekiö and the northern part of Sodankylä. In the year 2003 there were 7956 Sámi living in Finland, of whom 3669 lived in the Arctic Sámi area (Sámi Parliament, 2003). The material to be analysed consists of news photos published in the Arctic press, in this case the issues of Lapin Kansa appearing in the year 2006. I examine how an ethnic minority is depicted in a newspaper representing the norm population. Are the Sámi depicted as being as active as the Finns and in their real roles? What kind of valuations can be seen among the Sámi?

I do not know if the press photos are staged or not. I study how issues are represented, not the 'reality'. It is more interesting to investigate what kinds of choices a newspaper makes when selecting the photos than to determine if the representations reflect real life.

\section{Otherness}

After observing certain elements and settings in the news photos and lay-outs and evaluating which factors possibly are defining and creating power relationships, I will use the concept of otherness for summarising the impacts of a range of valuating issues.

In this research I use Pentti Raittila's definition of otherness:

Otherness is an ethnic difference compared to oneself and one's proximate social group. The basis for otherness can be the colour of the skin or other 'natural' differences of appearance, different manners, a different mentality, history, religion and other cultural features or political distinctions (east vs. west, north vs. south, 'we' vs, terrorists.)

(Raittila 2004, P.17)

Society consists of various groups and nations. They build their identities in relation to each other by searching for differences and creating stereotypes - recasting others in relation to themselves. Similarity is also needed when leaving the others outside and separated; otherness can not exist without a norm. Stereotyping is not necessarily a bad thing; it is needed for making sense of society. Stereotyping works through simplifying and exaggerating and can also take on racist forms when separating 'us' from 'them' if other groups are categorised as being less valuable than one's own near group (Hall, 1999, pp. 139-222). Stereotyping and producing otherness become a problem when they are used for justifying racist actions, as has happened in the 
colonial history of Europe. Others have been and are often oppressed through stereotyping by another group who has the power to determine relationships.

I will analyse journalistic pictures to determine the forms of otherness created by the representations. Just as pictures as representations make meanings, they also produce and strengthen the oppressed position of the others in relation to the norm. Can one discover otherness in news photos telling about the Sámi in relation to Finns or some other group? It might also be that the Sámi create others within their own group. For instance, Sámi women can be others in relation to Sámi men. That would mean that they are objects of double otherness.

\section{Previous research}

Sari Pietikäinen has studied ethnic representation in the Finnish media with a special focus on the Sámi people (Pietikäinen 2001). She and Jaana Hujanen have published an article about the representations of northern people and regions in Finnish news discourse (Hujanen \& Pietikäinen, 2003). They look at how northern people and regions are represented in the press and how these representations position people and regions in relation to public participation. They are also interested in whether northern people and regions are portrayed as mere targets of events and actions or as involved participants engaged in a dialogue. Hujanen and Pietikäinen have studied news texts using discourse analysis; my primary interest here is in visual representations. I study news photos, which affect readers' emotions more than texts do.

Since the beginning of the 1990s, photojournalism has received more attention from researchers. Realismista fiktioon (Brusila, 1997) is one of the first Finnish doctoral theses about photojournalism. Anne Koski analysed the role of photos and images as resources in international politics (Koski, 2005). Power in creating visual representations was the focus of Janne Seppänen's study (Seppänen, 2005). It is interesting also in the present study to examine who is using photojournalism as resource and who takes on the power in journalistic representations.

Edward Said used the term 'Other' for first time in his book Orientalism (Said, 1978). Orientalism means a Western view of the East. There is a difference between these cultures, and Western people have started to define what 'Oriental' means from their point of view. This is how otherness works also between other groups and cultures than oriental and occidental. Said did his study from the perspective of the other, being a member of an ethnic group. He observed how an ethnic group experiences otherness. I have a significantly different starting point in this study. I am interested in observing the otherness that Finns produce and reinforce through representations in the Finnish press in their relation to the Sámi. This is the same kind of standpoint on otherness that Raittila adopts in his doctoral thesis about the forms of otherness that the Russians and Estonians take on in Finland (Raittila, 2004).

The concept of otherness is applied extensively in postcolonial research, where it has been used for analysing subjugated groups such as women and ethnic groups. Colonial features can be seen in Finland in relation to the Sámi, one example being the attempts using skull measurements to make the Sámi look inferior to the Finns 
(Isaksson 2001, 189-221). Today's racism is not as transparent, but features of otherness can be observed in Finnish society.

In addition to Paavo Raittila, whom I mentioned above, Karina Horsti has studied multiculturality and otherness in Finnish journalism in her doctoral thesis Vierauden rajat. Horsti observed immigrant groups in relation to the Finns and found practices by which issues are made familiar or distant in journalism (Horsti, 2005).

A number of studies have been done in which the Sámi are observed in the role of others. For example, Andrea Amft has done research on the Sámi in Sweden and double otherness with a focus on Sámi women (Amft, 2001). In Finland, Rauna Kuokkanen has also studied Sámi women in her article 'Saamelaisnaiset, feministinen analyysi ja saamelaisyhteiskunnan dekolonisaatio' (Kuokkanen, 2004). I am also interested in the role of the women within the ethnic group and if manifestations of double otherness can be found among the Finnish Sámi.

\section{Materials}

There is no newspaper in the Sámi language in the Sámi area of Finland. Lapin Kansa, which represents the norm, is the biggest newspaper in this Arctic area. If the Sámi are active in this area they should get space in the news in Lapin Kansa despite their minor role. My material will be press photos published in Lapin Kansa in the year 2006 .

The journalists of Lapin Kansa have confirmed to me that the newspaper has a stated purpose to give the Sámi publicity. The newspaper has its main editorial office in Rovaniemi but it has also maintained its regional editorial offices, which means that journalists can work near the Sámi. Journalists often take photos when working on articles. Lapin Kansa belongs to AlmaMedia group, meaning that through the paper the news about the Sámi can spread widely in Finland also to other media.

In the year 2006, 679 articles were published in Lapin Kansa in which there was some mention of the Sámi. Of those articles, $40 \%$ were accompanied by photographs. Of these, I selected ones which represented the Sámi on the basis of the titles, captions, news texts or known visual symbols of the Sámi culture, such as the Sámi costume. The photos without persons were omitted, as were pictures in which the article itself did not frame the depicted persons as belonging to the Sámi. The final material to be analysed consisted of 114 news photos.

\section{Content Analysis}

I defined ten variables with several values in each for carrying out a content analysis of the material. The classification of the variables for the 114 Sámi pictures described above can be seen in Table 1. in the column 'Total \%'.

I wanted to examine the occupational photos in slightly greater detail. The column 'Occupational \%' shows the percentage of cases where the variable 'Role' takes on the value 'Occupational'. There were 25 occupational press photos in the material. 


\begin{tabular}{|c|c|c|c|c|c|}
\hline \multicolumn{6}{|c|}{ Table 1} \\
\hline Variable & Value & Total \% & Occupational \% & Male\% & Female \% \\
\hline \multirow[t]{4}{*}{ Setting } & 1.1 Culture & 36.8 & 36.0 & 26.1 & 54.5 \\
\hline & 1.2 Economy & 1.8 & 4.0 & 0 & 0 \\
\hline & 1.3 Public & 61.4 & 60.0 & 73.9 & 45.5 \\
\hline & 1.4 Sports & 0 & 0 & 0 & 0 \\
\hline \multirow[t]{3}{*}{ Size } & $2.1 \mathrm{Big}$ & 32.4 & 40.0 & 30.4 & 13.6 \\
\hline & 2.2 Standard & 28.1 & 16.0 & 21.7 & 31.8 \\
\hline & 2.3 Small & 39.5 & 44.0 & 47.8 & 54.5 \\
\hline \multirow[t]{5}{*}{ Position on page } & 3.1 Top right & 19.3 & 20.0 & 21.7 & 13.6 \\
\hline & 3.2 Top left & 21.1 & 32.0 & 21.7 & 18.2 \\
\hline & 3.3 Middle & 36.8 & 36.0 & 39.1 & 22.7 \\
\hline & 3.4 Bottom left & 11.4 & 8.0 & 4.3 & 31.8 \\
\hline & 3.5 Bottom right & 11.4 & 4.0 & 13.0 & 13.6 \\
\hline \multirow[t]{5}{*}{ Participants } & 4.1 Group & 41.2 & 48.0 & 0 & 0 \\
\hline & 4.2 Male & 20.2 & 8.0 & 100 & 0 \\
\hline & 4.3 Female & 19.3 & 20.0 & 0 & 100 \\
\hline & 4.4 Couple & 16.7 & 24.0 & 0 & 0 \\
\hline & 4.5 Child & 2.6 & 0 & 0 & 0 \\
\hline \multirow[t]{6}{*}{ Pose } & 5.1 Close-up & 4.4 & 0 & 21,7 & 0 \\
\hline & 5.2 Medium close-up & 16.7 & 20.0 & 17.4 & 40.9 \\
\hline & 5.3 Medium shot & 26.3 & 32.0 & 26.1 & 45.5 \\
\hline & 5.4 Full shot & 8.8 & 4.0 & 21.7 & 4.5 \\
\hline & 5.5 Wide shot & 17.5 & 20.0 & 13.0 & 9.1 \\
\hline & 5.6 Public & 26.3 & 24.0 & 0 & 0 \\
\hline \multirow[t]{2}{*}{ Behaviour } & 6.1 Active & 37.7 & 40.0 & 26.1 & 31.8 \\
\hline & 6.2 Passive & 62.3 & 60.0 & 73.9 & 68.2 \\
\hline \multirow[t]{3}{*}{ Position of participant } & 7.1 Subject & 32.5 & 32.0 & 4.3 & 31.8 \\
\hline & 7.2 Object & 2.6 & 4.0 & 0 & 0 \\
\hline & 7.3 Other & 64.9 & 64.0 & 73.9 & 68.2 \\
\hline \multirow[t]{4}{*}{ Role } & 8.1 Occupational & 21.9 & 100 & 8.7 & 22.7 \\
\hline & 8.2 Political & 7.0 & 0 & 8.7 & 0 \\
\hline & 8.3 Arts & 21.9 & 0 & 13.0 & 54.5 \\
\hline & 8.4 Other & 49.1 & 0 & 69.6 & 22.7 \\
\hline \multirow[t]{2}{*}{ Environment } & 9.1 Outdoors & 32.5 & 20.0 & 34.8 & 22.7 \\
\hline & 9.2 Indoors & 67.5 & 80.0 & 65.2 & 77.3 \\
\hline \multirow[t]{3}{*}{ Camera angle } & 10.1 Up-Down & 3.5 & 0 & 0 & 0 \\
\hline & 10.2 Direct & 93.9 & 100 & 95.7 & 95.5 \\
\hline & 10.3 Down-Up & 2.6 & 0 & 4.3 & 4.5 \\
\hline
\end{tabular}

The column 'Male \%' shows the percentage of cases where the variable 'Participants' takes on the value 'Male'. There were 23 press photos of men representing the Sámi culture in the data. This means that there was only one person depicted. Photos of two men, or a man and a woman, were categorised under 'Couple' and photos depicting a bigger group were categorised under 'Group'.

The column 'Female \%' shows the percentage of cases where the variable 'Participants' takes on the value 'Female'. There were 22 press photos of women representing the Sámi culture in the data. This means that there was only one person depicted. Photos of two women, or a woman and a man, were categorised under 'Couple' and photos depicting a bigger group were categorised under 'Group' . 


\section{Analysis of form}

The lay-out of the Sámi news tended to be placed in the middle of the page. The upper parts of the page were used more commonly than the less prominent lower parts of the page. This might indicate that the Sámi culture is considered an interesting issue and it has visually beautiful elements such as impressive costumes, which deserve visibility. The sizes of the photos varied evenly across the scale used and camera angle was mostly direct.

Most of the Sámi photos were placed on the daily news pages, a space which I call 'Public' in the table. Even news about reindeer races was under public news, not under the category 'Sports' as could be expected beforehand. The number of news items in the Culture section was significant. In contrast, the Sámi were rarely depicted in the financial news.

I examined all the pages and settings in Lapin Kansa during the week $19^{\text {th }}$ March to $25^{\text {th }}$ March of the year 2007. The proportion of culture pages was only $5.3 \%$. Compared with the number of culture settings in the Sámi representations in the year 2006, $36.8 \%$, it can be said that the Sámi are represented surprisingly often in this category.

Women were placed in slightly less prestigious spots in the layout than men. The size of the photos was also a little bit smaller when women were depicted.

\section{Beyond the data}

The Sámi were often depicted celebrating in costumes in different kinds of cultural events, which partly explains why the setting in the newspaper was so often 'Culture'. They were also frequently represented as artists in press photos (Fig.1). The number of artists in the total material was as high as that of all other occupations combined.

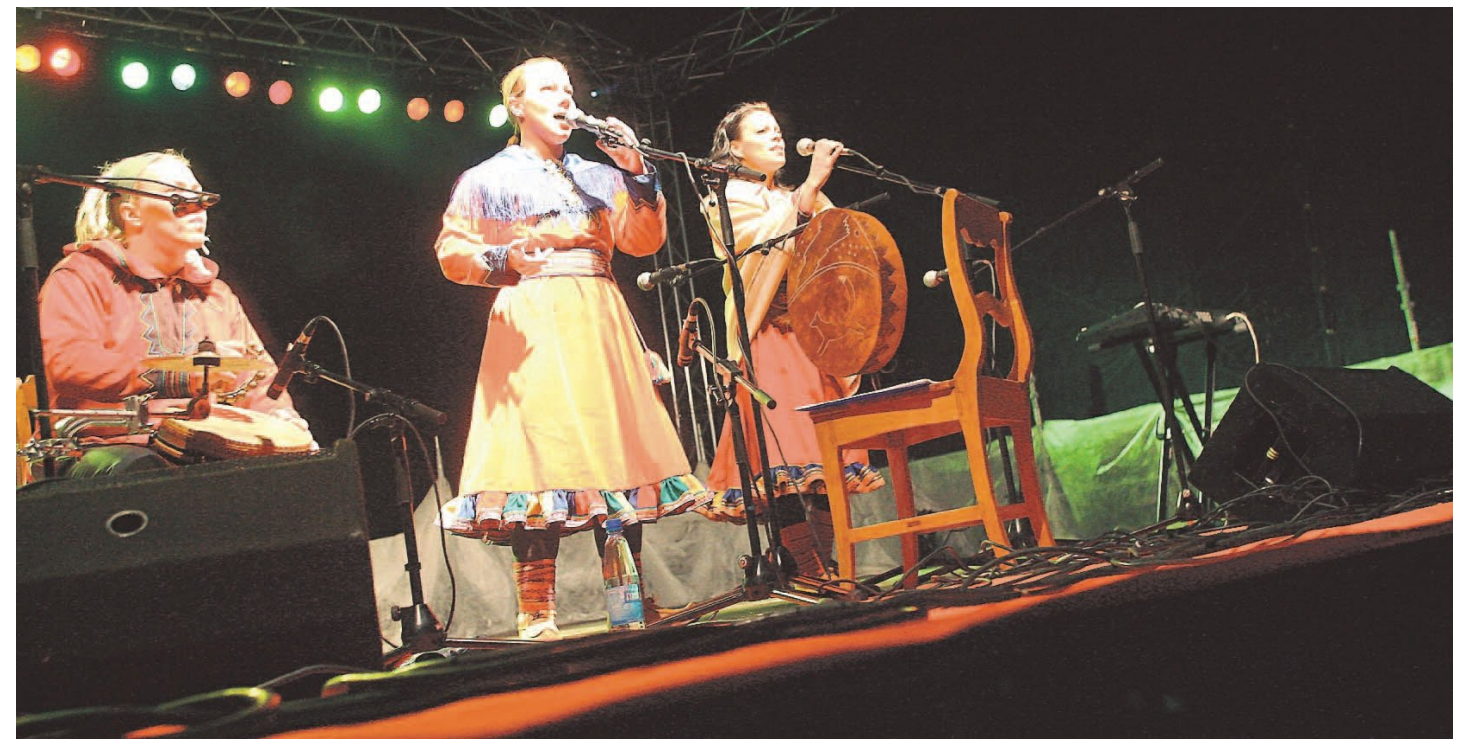

Figure 1. Angelit - the Sámi joik-singing duo Tuuni and Ursula Länsman - at the opening of the Christmas season. Accompanying them on the keyboard is Antti Rikkilä, from Savo. (26 November 2006). 
I made a deeper analysis of all the occupational photos, which were 25 in number. Even when the photos categorised under other values were eliminated, for example the remarkable number of 'Arts' photos, the amount of cultural news was still as high as in the total material. It seems that the Sámi culture and arts have a special power through their ethnic and exotic culture, which generates public interest.

The Sámi were seldom depicted in political roles or appeared in the economics section. The few economic and political roles belong to men, as could be expected beforehand. Those few political articles published in 2006 that were accompanied by photographs dealt mostly with politics inside the ethnic group, such as issues of the Sámi Parliament. It seems that the Sámi do not take on political or economic roles in Lapin Kansa; the power they have in the press is based more in art and culture. It might be that in everyday life the Sámi deal more with economy and politics than is represented in media, but the newspaper is more interested in depicting them in the context of celebrations, when the cultural difference shows up more via national costumes. Another explanation could be that the Sámi do not want to show their ethnicity in the media in political or economic contexts.

The Sámi were often depicted as a group (Fig.2), which I define as at least three people. This kind of representation can be an indication of prioritisation or otherness. As mentioned above, grouping and stereotyping are ways to make sense of society. Stereotyping simplifies issues, and people lose their personality when changing to a faceless mass. This kind of categorisation is called depersonalising and it is regarded as typical for representing outsiders or enemies (Liebkind, 1988). The number of group representations explains the high number of photos taken from a public distance. In a photo taken from a public distance one can see the whole figure of at least four of five persons.

Representations were disturbingly passive in general. The reason for the passiveness might be the large number of posing photos (Fig.2). Posing explains why the role of the depicted persons most often could be categorised as only 'other' and why even occupational representations are so passive. Photos are framed by the text as representing people in occupational roles but the photo itself rarely shows a person working and being an active subject instead of posing passively for the photographer.

In spite of numerous group representations, $58.8 \%$ of the photos of Sámi represented a couple or a woman, man or child alone. The number of photos of women and men was similar in the total material. I wanted to investigate in more detail the occupational roles and activity between genders. 


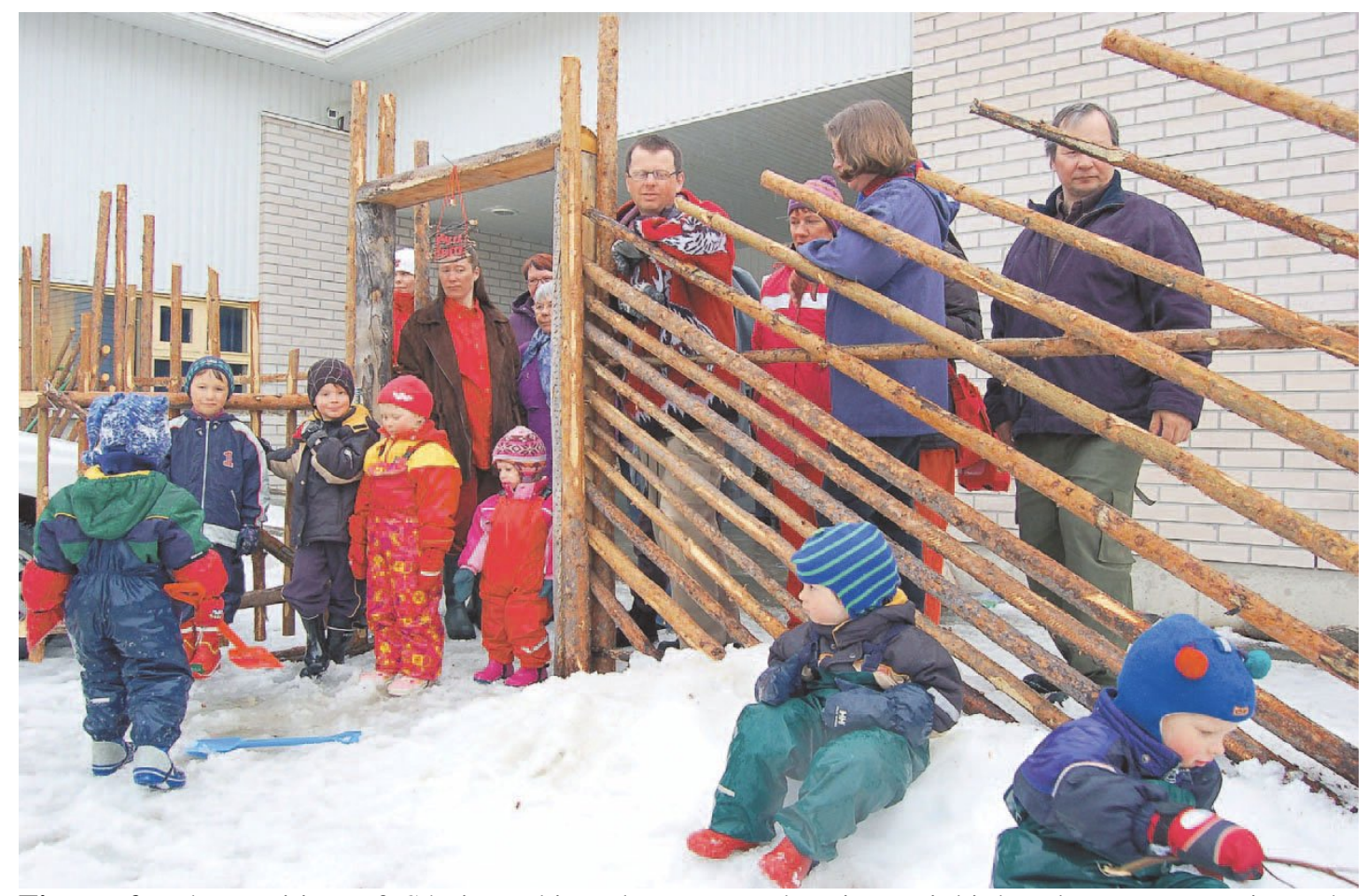

Figure 2. The position of Sámi-speaking daycare teacher in Utsjoki has been vacant since the beginning of March. Parents are concerned about the lack of interested applicants. (Lapin Kansa 22 April 2006)

Surprisingly, Sámi women were represented more often in occupational roles than men. It seems that Lapin Kansa does not subject Sámi women to double otherness. On the other hand, Sámi men had a minimal role in occupational news photos. One explanation for this observation may be that the occupations depicted are not those traditionally considered to be Sámi livelihoods, such as reindeer husbandry. Only one occupational photo dealt with reindeer husbandry in the whole year 2006. In contrast, women have a strong role in cultural occupations, which attract the attention of the media. Lapin Kansa often depicted the Sámi as artisans or leaders of cultural events in occupational photos.

Reindeer herding is thought of as the basis of Sámi culture, not for example art, and even today reindeer husbandry is the most important livelihood for the Sámi living in the Arctic area of Finland. In Sweden and Norway, reindeer herding is allowed only for the Sámi. Given the significance of this occupation, it seems odd that it is not represented more.

\section{Discussion}

The first thought about the large number of Sámi representations in cultural news is that this is a sign of high regard by Lapin Kansa for the ethnic minority of Finland. However, it might be that cultural news creates otherness by emphasising exotic and ethnic features of the Sámi culture.

Many Sámi representations refer to the past. There are for example several news items about the photo exhibitions in the year 2006, in which the published photos were taken in past decades (Fig.3). Also dancing photos, group photos and telling 
about the traditions multiply admiring earlier times and referring to the past. This contrasts with Western culture, which emphasises individualism, the present and being dynamic, and the Sámi. Lapin Kansa represents the norm population, who have a right to tell about the ethnic minority and redefine it. In this case, the Finns are the norm population and represent Western culture compared to the ethnic Sámi, who suddenly have became others in pictorial material.

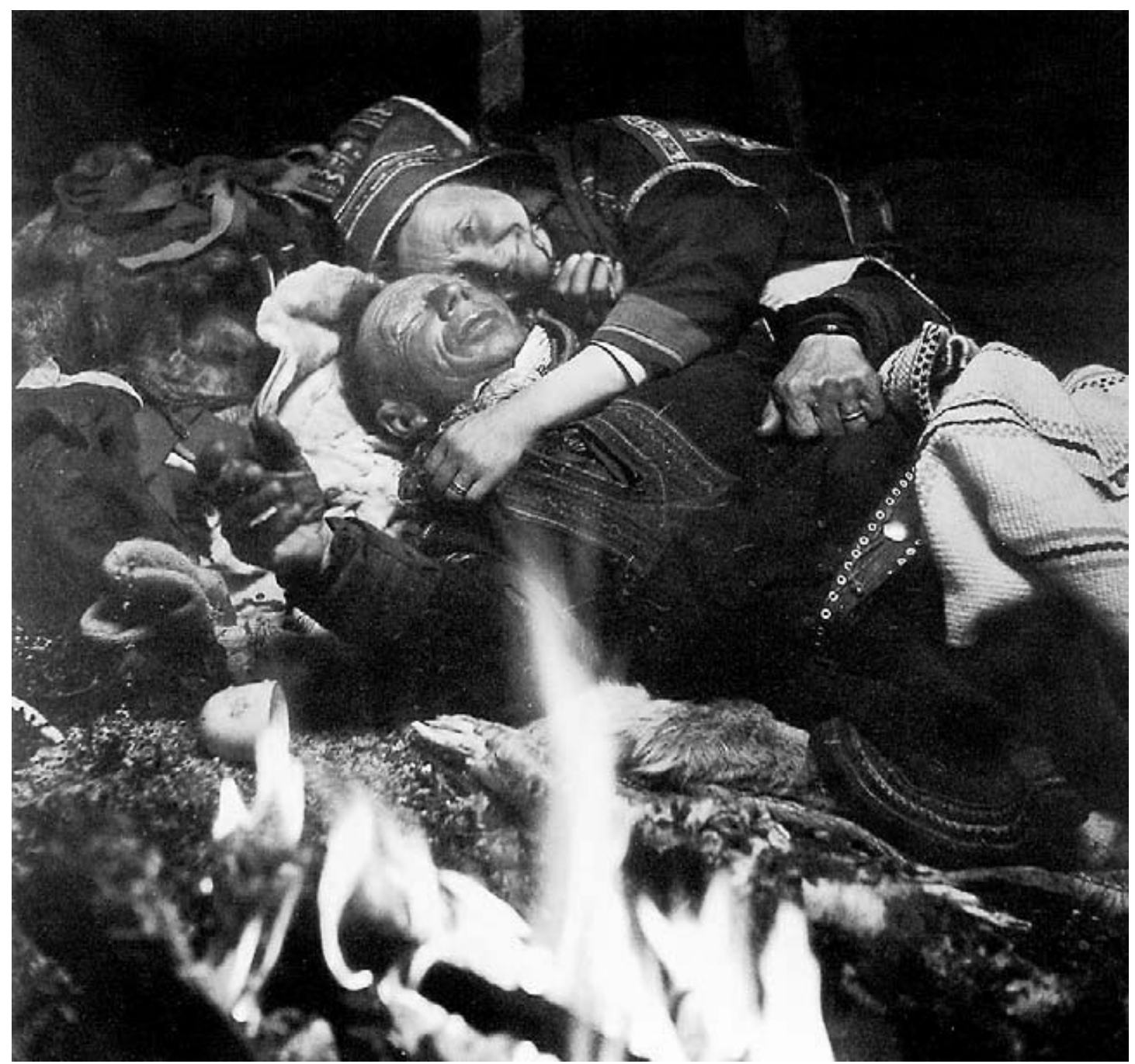

Figure 3. Spring migration took place on the last snows of May, and so the playful 'Mother's Day' hug Antti and his wife Piri-Hanne (Biret Anné, née. Buljo) gave each other was photographed on the trip at the Tuorkottajajärvi kota (tepee). Martti Linkola's caption brings the family history of Antti Antinpoika Näkkäläjärvi, known alos by the name Vilkunan-Antin (Vilgon Ándde), into this photo by Marja Vuorelainen. (Lapin Kansa 11 January 2006)

Western culture is a culture of men. In the Western world groups and cultures need masculine representations to be considered viable and functional. It seems fair that Lapin Kansa has a great deal of representations of active women, but it might be that these active women actually create otherness between the Sámi and the Finns. Or would it be better to say that the lack of men creates otherness, because in the Western world a man is a symbol of living culture?

Of course it is rather black and white to say that Lapin Kansa respresents the Sámi as others. There are several people working as journalists and photographers at the newspaper, and every one of which holds different kinds of representations. What the 
representations have in common is that Lapin Kansa has considered them all worth publishing. It means that they fit in with the norms and values of the paper.

In the future, it would be interesting to examine ethnicity in representations in greater detail, for example, from an anthropological or postcolonial point of view. I suppose it is very important to the Sámi to show their ethnicity also in the media in standing up for their rights as effectively as possible. I would like to find out why and when the Sámi use their costumes. Do they use the costumes mostly when celebrating, or, for example, in political contexts as well if it is important to show belonging to the ethnic group. Investigating these issues would require making several interviews among the Sámi in different kind of roles.

This analysis would require corroborative material from some other newspaper for deeper analysis and comparing the results. Newspaper Nordlys has a similar role in Norway as Lapin Kansa in Finland. The main editorial office of Nordlys is situated in Tromsö and it is the biggest newspaper in northern Norway, which is the most important Sámi area in Norway. As a next step for my research I will make a similar analysis for the Sámi photos of Nordlys in the year 2006 as I already made for the material of Lapin Kansa.

It will be especially interesting to investigate how Norlys has given space to Sámi news in the context of reindeer husbandry, because in Norway it is an even more important livelihood for the Sámi than in Finland. Most of the Sámi in the world live in Norway and Sámi culture is perhaps more familiar to the Norwegian mainstream population than to the Finnish. If Sámi culture is not considered as exotic in Norway as it is in Finland, the amount of culture news dealing with the Sámi may be smaller there than in the Finnish press.

\section{Conclusions}

The Sámi representations were in general passive group representations, which in my opinion suggests that Lapin Kansa as the medium of the norm population categorises the Sámi as others.

The occupational representations do not tell about the occupations which are most significant for the Sámi in the Arctic Sámi area, such as reindeer herding. The real everyday roles are minimal in the representations. Cultural events and occupations are depicted often, which increases the role of Sámi women in the representations. Indeed, it seems that otherness shows its positive power in the field of culture and arts in the representations of Lapin Kansa in the year 2006. However, the culture news emphasises the exotic features of the Sámi culture that refer to the past, and this might portray the Sámi as others compared to the idea of Western culture, which emphasises the present. 


\section{References}

Amft Andrea (2001) Woman in Samiland. Genus 1/01, 10-11.

Brusila Riitta (1997) Realismista fiktioon. University of Tampere.

Fairclough Norman (2002) Miten media puhuu. Vastapaino.

Hall Stuart (1999) Identiteetti. Vastapaino.

Horsti Karina (2005) Vierauden rajat. University of Tampere.

Hujanen Jaana, Pietikäinen Sari (2003) 'At the crossroads of ethnicity, place and identity: representations of northern people and regions in Finnish news discourse'. Media, Culture \& Society.25: 251-268.

Isaksson Pekka (2001) Kumma kuvajainen. Rasismi rotututkimuksessa, rotuteorioiden saamelaisetja suomalaisten fyysinen antropologia. Jyväskylä. Kustannus Puntsi.

Kaartinen Marjo (2004) Neekerikammo. Kirjoituksia vieraan pelosta. Turku. K\&H.

Koski Anne (2005) Niinkö on jos siltä näyttää. Episteme.

Kuokkanen Rauna (2004) Saamelaisnaiset, feministinen analyysi ja saamelaisyhteiskunnan dekolonisaatio. Pohjoistuulia. http://ktk.ulapland.fi/pohjoistuulia/pdf/kuokkanen.pdf

Liebkind Karmela (1988) Me ja muukalaiset - ryhmärajat ihmisten suhteissa. Helsinki. Gaudeamus.

Loiri Pekka ja Juholin Elisa (1998) Huom! Visuaalisen viestinnän käsikirja. Helsinki. Inforviestintä.

Miettinen Jorma (1980) Sanomalehtien lukeminen. Makuntien ykköslehtien lukijoiden kiinnostus sekä väline- ja sisältökäyttö. Espoo. Weilin Göös.

Naskali Päivi, Autti Mervi, Keskitalo-Foley Seija, Korhonen Anne, Kutuniva Mervi (ed.) (2003) Tuulia Feministisiä näkökulmia lappilaiseen sukupuolikulttuuriin. University of Lapland.

Pietikäinen Sari (2001) On the Fringe: News Representations of the Sami. University of Jyväskylä.

Raittila Pentti (2004) Venäläiset ja virolaiset suomalaisten Toisina. Tapaustutkimuksia ja analyysimenetelmien kehittelyä. University of Tampere.

Said E. (1978) Orientalism. New York: Random House. 
Sámi Parliament (2003) http://www.samediggi.fi/ , Saamelaisten lukumäärä 2003 vaaleissa

Seppänen Janne (2005) Visuaalinen kulttuuri. Vastapaino. 